\title{
THE INFLUENCE OF JOB INSECURITY ON JOB PERFORMANCE AND ABSENTEEISM: THE MODERATING EFFECT OF WORK ATTITUDES
}

\author{
ANTONIO CHIRUMBOLO \\ University "G. D'Annunzio" of Chieti-Pescara \\ ALESSANDRA ARENI \\ University "La Sapienza" of Rome
}

\begin{abstract}
Job insecurity was found to have relevant psychosocial consequences for both individuals and organisations Recently, research is increasingly focusing on those variables that can moderate its negative influences. In this study, the impact of job insecurity on two indicators of organisational behaviour (i.e. job performance and absenteeism) was investigated. It was expected that job insecurity was negatively related to job performance and positively to absenteeism, and that this relationship was moderated by work related attitudes, such as job satisfaction and organisational commitment. Four-hundred and twenty five workers were interviewed with a structured questionnaire. Overall, the hypotheses were supported by the data: job insecurity was in fact negatively correlated with job performance and positively with absenteeism. However, work related attitudes moderated only the effect of job insecurity on job performance but not on absenteeism.
\end{abstract}

\section{OPSOMMING}

Daar is gevind dat werksonsekerheid relevante psigososiale gevolge vir beide individue en organisasies inhou. Onlangse navorsing fokus al hoe meer op daardie veranderlikes wat die negetiewe effekte hiervan kan modereer. In hierdie studie is die impak van werksonsekerheid op twee indikatore van organisasiegedrag (werksprestasie en afwesigheid) ondersoek. Dit was verwag dat werkonsekerheid 'n negetiewe verhouding tot werksprestasie en 'n positiewe verhouding tot afwesigheid sou gehad het en dat hierdie verhouding gemodereer sou word deur werksverwante gesindhede, soos werkstevredenheid en organisasiegebondenheid. 425 werknemers is met 'n gestruktureerde vraelys ondervra. Die hipotese is oor die algemeen deur die data ondersteun: werksonsekerheid het inderdaad 'n negetiewe korrelasie tot werksprestasie en 'n positiewe korrelasie tot afwesigheid gehad. Werksverwante gesindhede het egter slegs die effek van werksonsekerheid op werksprestasie gemodereer, maar nie op afwesigheid nie.

Because of extreme competitive pressures, deregulations and rising costs, companies have been forced to restructure their organizations, in terms of business, finances, processes and structures. In the USA and Europe, phenomena such as merging, downsizing and reorganization have turned out to be more and more widespread in the last two decades (Burke \& Cooper, 2000). These transformations have changed the nature of work and caused feelings of uncertainty, stress and anxiety for many workers about the existence and the features of their job. As a matter of fact, job insecurity has been among the most investigated job stressors (see i.a. Ashford, Lee \& Bobko 1989; Greenhalgh \& Rosenblatt, 1984; Hartley, Jacobson, Klandermans \& van Vuuren, 1991; Sverke, Hellgren, Näswall, Chirumbolo, De Witte \& Goslinga, 2004). In the last twenty years, research has generated wide empirical evidence about the negative impact of job insecurity on a number of aspects related both to individuals' well being and to organisational functioning (see Sverke, Hellgren \& Näswall, 2002 for a review and a meta-analysis).

As regards the individual consequences, higher feelings of job insecurity were found to correlate with poorer mental and physical health (Ashford, Lee \& Bobko 1989; Barling \& Kelloway, 1996; Chirumbolo \& Hellgren, 2003; De Witte, 1999; Ferrie, Shipley, Marmot, Martikainen, Stansfeld \& Smith, 2001; Heaney, Israel \& House, 1994; Hellgren \& Sverke, 2003; Hellgren, Sverke \& Isaksson, 1999; Platt, Pavis \& Akram, 1999; Roskies \& LouisGuerin, 1990; Strazdins, D'Souza, Lim, Broom \& Rodgers, 2004), psychological distress and burn out (Dekker \& Schaufeli, 1995; Probst, 2002), worse psychological moods (Burke, 1998), lower self esteem (Kinnunen, Feldt \& Mauno, 2003), life dissatisfaction (Lim, 1996), spoiled marital and family relations (Fox \& Chancey, 1998; Hughes \& Galinsky, 1994; Larson, Wilson \& Beley, 1994; Westman, Etzion \& Danon, 2001; Wilson, Larson \& Stone, 1993).

Requests for copies should be addressed to: N De Cuyper,

nele.decuypre@psy.kuleuven.be
On the other hand, as regards the organisational consequences, higher feelings of job insecurity were associated to lower job satisfaction and organisational commitment (Ashford, Lee \& Bobko, 1989; Chirumbolo \& Hellgren, 2003; De Witte, \& Näswall, 2003; Lim, 1996; Hellgren, Sverke \& Isaksson, 1999; Van Vuuren, Klandermans, Jacobson \& Hartley, 1991), intention to quit the organization (Chirumbolo \& Hellgren, 2003; Davy, Kinicki \& Scheck, 1991; 1997; Dekker \& Schaufeli, 1995), reduced organisational trust (Ashford et al., 1989), proactive job search and noncompliant job behaviours (Lim, 1996), work withdrawal behaviours such as absenteeism, tardiness and task avoidance (Probst, 2002a), lower job performance (Abramis, 1994; Lim, 1997; Probst, 2002b), impaired safety outcomes such as higher levels of workplace injuries and accidents (Probst, 2004; Probst \& Brubaker, 2001).

Hellgren, Sverke and Isaksson (1999) distinguished between two different forms of job insecurity: a quantitative job insecurity, i.e. worrying about loosing the job itself, and a qualitative job insecurity, i.e. worrying about losing important job features. While the quantitative job insecurity is related to the general, comprehensive (and most used) operationalization of the construct, the qualitative job insecurity refers to feelings of potential loss in the quality of organisational position, such as worsening of working conditions, lack of career opportunities, decreasing salary development (Sverke \& Hellgren, 2002). However, these two different facets of job insecurity have in common the underlying assumption that job insecurity is intended to be a subjective experience, based on individual perception and understanding of the environment and the situation, and refers to the anticipation of the stressful event of losing the job itself (Sverke \& Hellgren, 2002). As one would expect, "objective" job insecurity, originated by situations such as organisational downsizing, restructuring, dismissals, generally leads to greater "subjective" job insecurity 
(Klandermans \& Van Vuuren, 1999; Hartley et al., 1991; Probst, 2003). However, feelings and perceptions of job insecurity may vary from one individual to another despite the objective situation they are currently living in (Greenhalgh \& Rosenblatt, 1984; Klandermans \& Van Vuuren, 1999; Hartley et al., 1991; Rosenblatt \& Ruvio, 1996). After all, literature on stress has widely documented that reactions to stress depend on how individuals cope with the situation they are facing (Lazarus \& Folkman, 1984), and has underlined the importance of internal resources (such as coping strategies, hardiness, and dispositional optimism) and external resources (such as material resources, social support) in coping with stress (see Parkes, 1994; Stroebe \& Stroebe, 1995).

Similarly, research on job insecurity is recently focusing on those intervening variables that could mitigate and reduce its negative consequences (Sverke \& Hellgren, 2002). It was suggested that individual differences in personality traits such as negative affect and self-care (Roskies, Louis-Guerin \& Fournier, 1993; Mak \& Mueller, 2000), self-esteem and optimism (Makikangas \& Kinnunen, 2003), emotional intelligence (Jordan, Ashkanasy \& Hartel, 2002), locus of control and need for security (Ashford et al., 1989; Greenhalgh \& Rosenblatt, 1984) may moderate the negative effects of job insecurity on well being outcomes. On the other hand, external resources such as social support (Lim, 1996), perceptions of process and work control (Barling \& Kelloway, 1996; Tetrick \& LaRocco, 1987), participations in decision processes (Parker, Chmiel \& Wall, 1997), fairness of treatment and organisational justice were shown to affect work attitudes (like satisfaction and commitment) and well being, and thus may moderate the effects of job insecurity (Sverke \& Hellgren, 2002).

Following this line of research, the present study is aimed to investigate the impact of job insecurity on two indicators of organisational outcomes (i.e. job performance and absenteeism) and explore the potential moderation role of work attitudes that are strictly related to perceived organisational fairness and support, such as job satisfaction and organisational commitment (Rohades \& Eisenberger, 2002).

Sverke, Hellgren and Näswall (2002) made a theoretical distinction between short-term and long-term reactions to job insecurity. According to the authors, some kind of reactions, like work attitudes, would arise closer in time to the stress experience with respect to some others that are expected to emerge after a longer period of time, like behaviours and health complaints. There is empirical evidence proving that job insecurity is more strongly related to short-term outcomes (e.g. job satisfaction, organisational commitment) than to long-term reactions affecting the organization (e.g. performance, withdrawal behaviours like turnover intention, absenteeism, lateness and so on) (Sverke et al., 2002).

Therefore, firstly it is expected that job insecurity is negatively related to job satisfaction and organisational commitment (Hypothesis 1); secondly that job insecurity is negatively related to job performance and positively related to absenteeism (Hypothesis 2).

However, the most important predictions of this contribution concern the moderating role of work attitudes with respect to the impact of job insecurity on organisational outcomes. As previously stated, there is empirical evidence that different forms of perceived social and organisational support (e.g. family support, managerial support) may affect or reduce the negative consequences of job insecurity. Based on social exchange theory, perceived organisational support was conceptualised as employees' beliefs concerning the extent to which the organization values their role, treat them fairly and cares about their well-being in general (Eisenberger, Huntington, Hutchinson \& Sowa, 1986). Thus, perceived organisational justice and support generate positive attitudes towards the organization and its activities, and are usually associated with more favourable evaluation of the organization, more satisfaction and more commitment (Rohades \& Eisenberger, 2002). In turn, job satisfaction and organisational commitment predict job performance (Angle \& Lawson, 1994; Judge, Thoresen, Bono \& Patton, 2001; Leong, Randall \& Cote, 1994; Meyer, Paunonen, Gellatly, Coffin \& Jackson, 1989; Riketta, 2002). In fact, in two meta-analytic studies the mean true correlation between overall job satisfaction and job performance was estimated to be .30 (Judge, Thoresen, Bono \& Patton, 2001) and .20 between organisational commitment and job performance (Riketta, 2002). It might be argued that if, to some extent, higher levels of job satisfaction and organisational commitment reflect higher perceived organisational support, then they may moderate the effects of job insecurity on the longterm organisational consequences (i.e. job performance and absenteeism). More precisely, the following hypotheses are stated:

Hypothesis 3a: job satisfaction moderates the effect of job insecurity on job performance: namely, workers who perceive a high level of job insecurity in combination with a high level of job satisfaction will rate their job performance superior as compared to those perceiving high job insecurity together with low job satisfaction;

Hypothesis 3b: job satisfaction moderates the effect of job insecurity on absenteeism: that is to say that workers who perceive a high level of job insecurity in combination with a high level of job satisfaction will report as having been less absent from work as compared to those perceiving high job insecurity together with low job satisfaction;

Hypothesis $3 c$ : organisational commitment moderates the effect of job insecurity on job performance: more precisely, workers who perceive a high level of job insecurity in combination with a high level of organisational commitment will assess their job performance as greater than those perceiving high job insecurity together with low organisational commitment;

Hypothesis 3d: organisational commitment moderates the effect of job insecurity on absenteeism: i.e. workers who perceive a high level of job insecurity in combination with a high level of organisational commitment will report to have been less absent from work as compared to those perceiving high job insecurity together with low organisational commitment.

\section{METHOD}

\section{Participants}

Four-hundred and twenty five workers participated in this study (219 males and 203 females; 3 neglected to state their gender). The average age of the participants was 37,5 years old ( $s d=10,63$ ), ranging from 18 up to 63 years old. Approximately $41.8 \%$ stated that they were married, while $44,7 \%$ declared that they were single. As regards education, $20,7 \%$ had a University degree, $70,1 \%$ had a secondary school degree, while the remaining $9.3 \%$ completed only primary school. The majority of the participants worked for private firms $(64,9 \%)$, while $35,1 \%$ worked for a public company. As regards occupational positions, $72,5 \%$ had a full time job and $64,8 \%$ had a permanent job (compared to $35,2 \%$ who had a temporary job); on average, participants worked for 11.3 years $(\mathrm{sd}=10,23)$, ranging from less than 1 year up to 42 years of work. About $21 \%$ were union members (mean= 13,1 years).

\section{Measures and procedures}

The study was conducted by autumn 2003 as part of a larger survey on related topics. Participants were administered a questionnaire by three interviewers, who were at the time undergraduate psychology students. Participants were contacted 
individually by the interviewers and then asked to volunteer for a survey on social and work attitudes. The questionnaire, on average, was completed in about 30 minutes, and contained the following measures:

$J o b$ insecurity. Job insecurity was measured using five items focusing on workers' perception and worry of whether they would be able to keep their current job. This scale was fruitfully employed in previous cross-cultural studies, exhibiting excellent validity and reliability (i.a. Chirumbolo \& Hellgren, 2003; Sverke, Hellgren, Näswall, Chirumbolo, De Witte \& Goslinga, 2004). Examples of items were: "I fear I will lose my job" and "I am sure I can keep my job" (reverse scored item). Participants were asked to express their own agreement/disagreement with the statements on a Likert scale (from 1=strongly disagree; to $5=$ strongly agree). The scale reached a Cronbach alpha of 0.81 . High scores indicate higher levels of job insecurity.

Job satisfaction. Job satisfaction was assessed with five items measuring the overall satisfaction with the present job (see De Witte, 2000; Hellgren, Sjöberg \& Sverke, 1997). Participants were asked to express their agreement/disagreement with statements such as "I am very satisfied with my job" on a Likert-scale ranging from 1 (strongly disagree) to 5 (strongly agree). This scale was effectively employed in previous cross-cultural studies, exhibiting excellent validity and reliability (Sverke et al., 2004). In this study it reached a Cronbach alpha of 0,86 with high scores indicating increased job satisfaction.

Organisational commitment. Organisational commitment was measured using five items referring to the affective attachment towards the organisation (Allen \& Meyer, 1990). A sample item is "I feel emotionally attached to my organisation". Participants expressed their agreement/ disagreement on a five-point scale (from 1 = strongly disagree; to $5=$ strongly agree) such that higher scores indicate stronger organisational commitment. This scale was effectively employed in previous cross-cultural studies, showing excellent validity and reliability (Sverke et al., 2004). In the present study, the scale reached a Cronbach alpha of 0,89 .

Job performance. Two items assessed overall job performance. The first item was "I achieved all my job goals in the last six months" to which participants had to state their agreement/disagreement ( 1 = strongly disagree; 5 = strongly agree). The second item was "In the last six months, your job performance was:" to which participants had to answer using a five point scale ranging from 1 $=$ Low, to $5=$ High. These two items were significantly correlated $(\mathrm{r}=0,38, \mathrm{p}<0,001)$ and thus were aggregated to form a composite index of self rated job performance.

Absenteeism. Absenteeism was operationalised with a single item measure by asking how many days the interviewee was absent from work in the last six months.

\section{Analysis of the data}

According to Baron and Kenny (1986), a variable (M) is said to moderate the relation of an independent variable $(\mathrm{X})$ on a dependent variable $(\mathrm{Y})$ when the strength of the association between $\mathrm{X}$ and $\mathrm{Y}$ depends on different levels of $\mathrm{M}$. In general, moderator effects are indicated by the interaction of $\mathrm{X}$ and $\mathrm{M}$ in explaining $\mathrm{Y}$, so that the following multiple regression equation must be calculated:

$$
\mathrm{Y}=\mathrm{a}+\mathrm{b}_{1} \mathrm{X}+\mathrm{b}_{2} \mathrm{M}+\mathrm{b}_{3} \mathrm{X}{ }^{\star} \mathrm{M}+\mathrm{e}
$$

The interaction between $\mathrm{X}$ and $\mathrm{M}$, as shown by the product term $\mathrm{X}^{*} \mathrm{M}$, measures the moderation effect. As suggested by Aiken and West (1991), before conducting the analyses, all the variables were standardized. Next, the two standardized predictors were multiplied to form the interaction term. The moderation was then tested via hierarchical regression analysis. The variables were regressed on the criteria (i.e. job performance and absenteeism in turn) with the predictors entered in the first step, followed by the interaction term in the second step (see Aiken \& West, 1991, for more details).

\section{RESULTS}

Descriptive statistics of the scales and correlations among the variables are reported in Table 1.

TABLE 1

DESCRIPTIVE STATISTICS AND CORRELATIONS AMONG THE VARIABLES

\begin{tabular}{lccccccc}
\hline & 1 & 2 & 3 & 4 & 5 & $\mathbf{M}$ & ds \\
\hline 1.Organisational Commitment & 1 & & & & & 2,97 & 1.01 \\
2.Job satisfaction & $0,72 *$ & 1 & & & & 3,27 & 0,89 \\
3.Job insecurity & $-0,24^{*}-0,19 *$ & 1 & & & 2,67 & 0,98 \\
4.Job performance & $0,46^{*}$ & $0,55^{*}$ & $-0,21^{*}$ & 1 & & 3,19 & 0,88 \\
5.Absenteeism & $-0,36^{*}-0,30^{*}$ & 0,23 & $-0,25^{*}$ & 1 & 6,05 & 3,15 \\
\hline
\end{tabular}

${ }^{*} \mathrm{P}<0,001$

As expected, job insecurity was negatively correlated to job satisfaction $(r=-0,19, p<0,001)$ and organisational commitment $(\mathrm{r}=-0,24, \mathrm{p}<0,001)$. Job insecurity was also negatively correlated to job performance $(r=-0,21, p<0,001)$ and positively related to absenteeism $(r=0,23, p<0,001)$. Additionally, job satisfaction and organisational commitment were found to be positively correlated to job performance and negatively to absenteeism (see Table 1). Overall, both hypothesis 1 and 2 were confirmed: job insecurity had a negative impact on work attitudes and organisational functioning.

In order to test the moderating hypothesis $3 \mathrm{a}$, a hierarchic regression analysis was conducted using job insecurity, job satisfaction and the interaction term as predictors and job performance as criteria. The variables were entered in two steps. In the first step, job insecurity and job satisfaction were included in the equation as predictors, then the multiplicative term job insecurity*job satisfaction was entered.

In the first step, both job insecurity $(\beta=-0,11, t=-2,47)$ and job satisfaction ( $\beta=0.44, t=9,91)$ showed a significant influence on job performance, explaining a significant proportion of variance of the criteria $\left(\mathrm{R}^{2}=0,32 ; \mathrm{F}(2,422)=98,90, \mathrm{p}<0,001\right)$. However, most importantly, in the second step also the interaction term significantly predicted job performance $(\beta=0,11, t=2,71)$. [Refer to Table 2 for $\beta, R^{2}$ change and Fchange statistics].

TABLE 2

Regression ANALYsis

\begin{tabular}{lcccc}
\hline Predictors $\backslash$ Criteria & \multicolumn{2}{c}{ Job performance } & \multicolumn{2}{c}{ Absenteeism } \\
\hline & Step1 & Step2 & Step1 & Step2 \\
\hline Job insecurity & $-0,011^{* *}$ & $-0,12^{* *}$ & $0,18^{* *}$ & $0,18^{* *}$ \\
Job satisfaction & $0,53^{* *}$ & $0,53^{* *}$ & $-0,27^{* *}$ & $-0,26^{* *}$ \\
Job_ins*Job_Sat & $==$ & $0,11^{* *}$ & $==$ & $-0,06$ \\
$\mathrm{R}^{2}$ & $0,32^{* *}$ & $0,33^{* *}$ & $0,12 * *$ & $0,12^{* *}$ \\
R2change & $==$ & $0,01^{*}$ & $==$ & 0,00 \\
Fchange & $98,90 * *$ & $7,35^{* *}$ & $28,66^{* *}$ & 1,61 \\
\hline
\end{tabular}

* $\mathrm{P}<0,05$ ** $\mathrm{P}<0,01$ 
In order interpret the direction of the interaction, a slope examination was conducted plotting the predicted values of job performance in function of job insecurity scores and three different levels of job satisfaction: low (one standard deviation below the mean), medium (the mean) and high (one standard deviation above the mean). As shown in Figure 1 , job performance decreases when job insecurity is higher and job satisfaction is low or medium. However, there is no influence of job insecurity on job performance when job satisfaction is high. That is to say that job satisfaction moderates the impact of job insecurity on performance: hypothesis $3 a$ was fully supported.

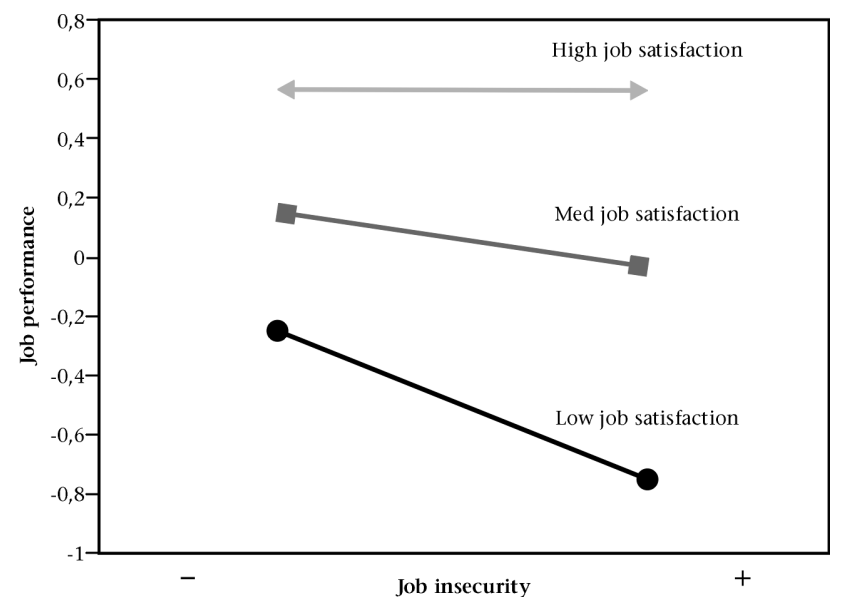

Figure 1: Slope plots: Job performance in function of Job insecurity and job satisfaction

In order to test hypothesis $3 b$, the same procedure was followed, employing absenteeism as criteria. In the first step, job insecurity and job satisfaction were included in the equation, then in step 2 the multiplicative term job insecurity*job satisfaction was entered.

In the first step, both job insecurity $(\beta=0,18, \mathrm{t}=3,80)$ and job satisfaction $(\beta=-0,27, t=-5,72)$ showed a significant impact on absenteeism, explaining a significant proportion of variance of the criteria $\left(R^{2}=0,12 ; F(2,422)=28,66, p<0,001\right)$. However, in the second step the interaction term did not predict absenteeism $(\beta=-0,06, t=-1,27)$. [See table 2 for $\beta \hat{a}, R^{2}$ change and Fchange statistics]. In this case, job satisfaction does not appear to moderate the negative influence of job insecurity on absenteeism: thus hypothesis $3 \mathrm{~b}$ was not supported.

In order to test hypothesis $3 \mathrm{c}$, job insecurity and organisational commitment were included in the equation as predictors in the first step, then the multiplicative term job insecurity* organisational commitment was entered in step 2. In this case, job performance was the criteria.

In the first step, both job insecurity $(\beta=-0,11, \mathrm{t}=-2,74)$ and organisational commitment $(\beta=0,53, t=13,03)$ showed a significant effect on job performance, explaining a significant proportion of variance of the criteria $\left(\mathrm{R}^{2}=0,22 ; \mathrm{F}(2,422)=\right.$ $61,40, p<0,001)$. Most importantly, in the second step the interaction term significantly predicted job performance $(\beta=0,12, \mathrm{t}=2,76)$. [See table 3 for $\beta, \mathrm{R}^{2}$ change and $\mathrm{F}$ change statistics].

In order interpret the direction of the interaction, a slope examination was conducted plotting the predicted values of job performance in function of job insecurity scores and three levels organisational commitment: low (one standard deviation below the mean), medium (the mean) and high (one standard deviation above the mean). As shown in Figure 1 , job performance decreases when job insecurity is higher and organisational commitment is low or medium. However, when organisational commitment is high, there is a slight positive influence of job insecurity on job performance. In fact it seems that organisational commitment acts as a moderator of job insecurity on job performance: hypothesis $3 \mathrm{c}$ was fully supported.

TABLE 3

REgRESSION ANALYSIS

\begin{tabular}{lcccc}
\hline Predictors $\backslash$ Criteria & \multicolumn{2}{c}{ Job performance } & \multicolumn{2}{c}{ Absenteeism } \\
\hline & Step1 & Step2 & Step1 & Step2 \\
\hline Job insecurity & $-0,011^{*}$ & $-0,11^{*}$ & $0,15^{* *}$ & $0,15^{* *}$ \\
Org. Committment & $0,44^{* *}$ & $0,44^{* *}$ & $-0,32^{* *}$ & $-0,32^{* *}$ \\
Job_ins*Org_Comm & $==$ & $0,12^{* *}$ & $==$ & $-0,00$ \\
$\mathrm{R}^{2}$ & $0,22^{* *}$ & $0,24^{* *}$ & $.15^{* *}$ & $0,15^{* *}$ \\
$\mathrm{R}^{2}$ change & $==$ & $0,02^{* *}$ & $==$ & 0,00 \\
Fchange & $61,40^{* *}$ & $7,60^{* *}$ & $37,04^{* *}$ & 0,00 \\
\hline
\end{tabular}

* $\mathrm{P}<0,05 * * \mathrm{P}<0,01$

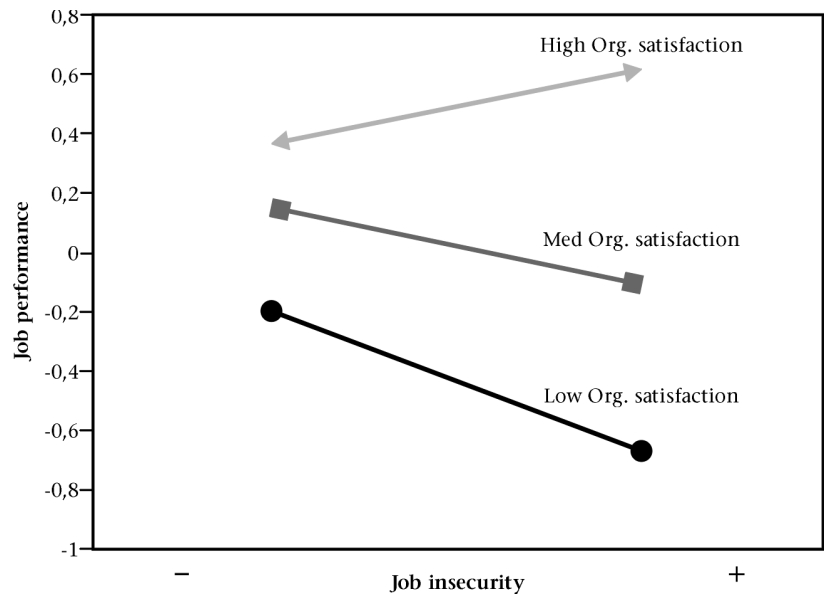

Figure 2: Slope plots: Job performance in function of Job insecurity and organisational commitment

To test hypothesis $3 \mathrm{~d}$, the same procedure was used employing absenteeism as criteria. In the first step, both job insecurity $(\beta=$ $, 15, \mathrm{t}=2,25)$ and organisational commitment $(\beta=-0,32, \mathrm{t}=-6,97)$ significantly affected absenteeism, explaining a significant proportion of variance of the criteria $\left(\mathrm{R}^{2}=0,15 ; \mathrm{F}(2,422)=\right.$ $37,04, p<0,001)$. However, in the second step the interaction term did not predicted absenteeism $(\beta=0,00)$. [Refer to Table 3 for $\beta, \mathrm{R}^{2}$ change and Fchange statistics]. In this case, organisational commitment does not appear to moderate the negative influence of job insecurity on absenteeism: thus hypothesis $3 d$ was not supported.

\section{DISCUSSION}

As some authors pointed out (Hartley et al, 1991; Sverke \& Hellgren, 2002), the psycho-social factors that may intervene and moderate the negative outcomes of job insecurity represents a fruitful area of research from both the individual and the organisational perspective. Even if those factors can not modify the source of stress itself (i.e. they do not change the insecure employment situation into a more secure one), they may have beneficial effects for the individual and the organisation preventing the occurrence of the most negative outcomes, presumably through reducing the likelihood that job insecurity is perceived as stressful. 
The main goal of the present study was to investigate the potential moderating role of work and organisational attitudes on the relationship between job insecurity and its organisational outcomes. Empirical evidence provided partial support to these expectations. Firstly, replicating previous results (e.g. Ashford et al., 1989; Davy et al, 1997; Hartley et al, 1991; Lim, 1996; Probst, 2002; Rosenblatt \& Ruvio, 1996; Sverke et al., 2004), job insecurity was shown to have a negative impact to short-term organisational outcomes, namely job satisfaction and organisational commitment, as well as to long-term reactions, like job performance and absenteeism. Moreover, job satisfaction and organisational commitment were found to be positively correlated to job performance and negatively to absenteeism (Judge et al., 2001; Riketta, 2002). Nevertheless, this study has also shown that both job satisfaction and organisational commitment moderate the negative effects of job insecurity on job performance. More precisely, job insecurity exhibited its negative influence on performance only in conditions of lesser job satisfaction and lesser organisational commitment. On the contrary, when job satisfaction and organisational commitment were sufficient high, the influence of job insecurity on performance vanished. That is to say, regardless of job insecurity there is no difference in job performance rated by employees if job satisfaction and organisational commitment are high. No moderation effect was found as regards absenteeism: specifically, job insecurity, job satisfaction and organisational commitment do not interact each other in predicting employees' counter-productive behaviour like absenteeism. However, they have a main independent effect.

From a managerial perspective these results appear relevant for more effective human resource management. In fact, if on one hand this investigation has confirmed the negative influence of job insecurity on organisational outcomes, on the other hand it has underlined the importance of positive work attitudes in buffering some negative outcomes for the organization itself. Therefore, managers and employers should take into account that insecurity is detrimental for the organization, and try to cope with this phenomenon and prevent its negative reactions by enhancing employees' satisfaction and commitment, intervening, for instance, on their antecedents (e.g. Allen \& Meyer, 1990; Cranny, Smith \& Stone, 1992; Ostroff, 1992; Mathieu, 1991; Spector, 1997).

The present study has, still, some limitations. One shortcoming is represented by the measure of job performance used here. Several authors have pointed out the problematic issue of measuring performance through self-report questionnaires (Sverke, Hellgren \& Naswall, 2002). There is empirical evidence that individuals tend to overrate their performance and that ratings of performance done by others (e.g. managers or colleagues) are usually more valid than selfrated performance measures (Ford \& Noe, 1987). Moreover, job performance seem to be a multidimensional construct with a complex latent structure (Scullen, Mount \& Goff, 2000). Therefore, it must be underlined that the promising results obtained in this study should be replicated in future research employing multiple measures of job performance, distinct from self report ratings.

Another problematic issue is the direction of the relationship between job insecurity and its supposed reactions. Although the present research was built upon a theoretical model derived from stress theory (Lazarus \& Folkman, 1984; Jex, 1998; Stroebe \& Stroebe, 1995), in which job insecurity is conceptualised as a stressor that would affect specific organisational behaviours and individuals' well-being (Ashford et al 1989; Davy et al., 1991; Greenhalgh, \& Rosenblatt, 1984; Sverke \& Hellgren, 2002), correlational data do not allow to draw causal conclusions, resulting in a lack of internal validity of the research. In fact, it is also possible that employees dissatisfied with their job and not committed with the organization, achieve poor performance. Furthermore, they tend to carry out withdrawal behaviours and are also the ones more likely to experience job insecurity and to react more negatively to it (Hartley et al., 1991). The correlational data presented in this study cannot exclude this alternative explanation. Nevertheless, some empirical evidence provided by panel or experimental research seem to support the causal interpretation of the relationship and the validity of the theoretical model. A few longitudinal studies, in fact, illustrate that job insecurity, after controlling for prior level of well-being, actually predicts subsequent psychological well-being and physical complaints (e.g. Frese, 1985; Hellgren $\&$ Sverke, 2003). Moreover, in a field experiment, Probst (2003) found that organisational restructuring affected employees' perceptions of job security and had consequences on organisational commitment, turnover and psychological well-being. Likewise, in another laboratory experiment (Probst, 2002b) it was found that the threat of layoffs resulted in a lower quality of performance and in a greater violation of safety rules.

In conclusion, the cost of increasing flexibility and uncertainty of the job market appears to be considerable from social, individual as well as organisational perspectives. If some outcomes of job insecurity can have a direct effects for the individual and indirect impact on the organization (e.g., the case of mental and physical health), others instead tend to be directly damaging for the organization and only indirectly for the individual (e.g. the case of job satisfaction, organisational commitment and job performance) as was shown in this investigation.

\section{REFERENCES}

Abramis, D. J. (1994). Relationship of job stressors to job performance: Linear or an inverted-U? Psychological Reports, 75, 547-558.

Allen, N. J. \& Meyer, J. P. (1990). The measurement and antecedents of affective, continuance, and normative commitment to the organization. Journal of Occupational Psychology, 63, 1-18.

Angle, H. L. \& Lawson, M. B. (1994). Organizational commitment and employees' performance ratings: both type of commitment and type of performance count. Psychological Reports, 75, 1539-51.

Ashford, S. J., Lee, C. \& Bobko, P. (1989). Content, cause, and consequences of job insecurity: A theory-based measure and substantive test. Academy of Management Journal, 32, 803829.

Barling, J. \& Kelloway, E. K. (1996). Job insecurity and health: The moderating role of workplace control. Stress Medicine, 12, 253-259.

Burke, R. J. \& Cooper, C. L. (Eds.). (2000). The organization in crisis; Downsizing, restructuring, and privatization. Oxford: Blackwell.

Burke, R. J. (1998). Job insecurity in recent business school graduates: Antecedents and consequences. International Journal of Stress Management, 5, 113-119.

Chirumbolo, A. \& Hellgren, J. (2003). Individual and Organizational consequences of Job Insecurity: a European study. Economic and Industrial Democracy, 24, 215-238.

Cranny, C. J., Smith, P. C. \& Stone, E. F. (1992). Job satisfaction: How people feel about their jobs and how it affects their performance. New York: Lexington.

Davy, J. A., Kinicki, A. J. \& Scheck, C. L. (1991). Developing and testing a model of survivor responses to layoffs. Journal of Vocational Behavior, 38, 302-317.

Davy, J. A., Kinicki, A. J. \& Scheck, C. L. (1997). A test of job security's direct and mediated effects on withdrawal cognitions. Journal of Organizational Behavior, 18, 323-349. 
De Witte, H. (1999). Job insecurity and psychological well-being: Review of the literature and exploration of some unresolved issues. European Journal of Work and Organizational Psychology, 8, 155-177.

De Witte, H. \& Näswall, K. (2003). "Objective" vs. "Subjective" job insecurity: Consequences of temporary work for job satisfaction and organizational commitment in four European countries. Economic and Industrial Democracy, 24, 209-312.

Dekker, S. \& Schaufeli, W. B. (1995). The effects of job insecurity on psychological health and withdrawal: a longitudinal study. Australian Psychologist, 30, 57-63.

Ferrie, J. E., Shipley, M. J., Marmot, M. G., Martikainen, P., Stansfeld, S.A. \& Smith, G. D. (2001). Job insecurity in white collar workers: Toward an explanation of association with health. Journal of Occupational Health Psychology, 6, 26-42.

Ford, K. J. \& Noe, R. A. (1987). Self-assessed training needs: The effects of attitudes toward training, managerial level, and function. Personnel Psychology, 40, 39-53.

Fox, G. L. \& Chancey, D. (1998). Sources of economic distress: Individual and family outcomes. Journal of Family Issues, 19, 725-749.

Eisenberger, R., Huntington, R., Hutchinson, S. \& Sowa, D. (1986). Perceived organizational support. Journal of Applied Psychology, 71, 500-507.

Greenhalgh, L. \& Rosenblatt, Z. (1984). Job insecurity: Toward conceptual clarity. Academy of Management Review, 9 (3), 438-448.

Hartley, J., Jacobson, D., Klandermans, B. \& van Vuuren, T. (1991). Job insecurity. London: Sage Publications.

Heaney, C. A., Israel, B. A. \& House, J. S. (1994). Chronic job insecurity among automobile workers: Effects on job satisfaction and health. Social Science \& Medicine, 38, 1431-1437.

Hellgren, J. \& Sverke, M. (2003). Does job insecurity lead to impaired well-being or vice versa? Estimation of cross-lagged effects using latent variable modelling. Journal of Organizational Behavior, 24, 215-236.

Hellgren, J., Sverke, M. \& Isaksson, K. (1999). A two-dimensional approach to job insecurity: Consequences for employee attitudes and well-being. European Journal of Work and organizational Psychology, 8, 179-195.

Hughes, D. L. \& Galinsky, E. (1994). Work experiences and marital interactions: Elaborating the complexity of work. Journal of Organizational Behavior, 15, 423-438.

Kinnunen, U., Feldt, T. \& Mauno, S. (2003). Job insecurity and self-esteem: Evidence from cross lagged relations a 1 year longitudinal sample. Personality and Individual Differences, $35,617-632$

Jex, S. M. ( 1998). Stress and job performance. Thousand Oaks, CA: Sage.

Jordan, P. J, Ashkanasy, N. M. \& Hartel, C. E. J. (2002). Emotional intelligence as a moderator of emotional and behavioral reactions to job insecurity. Academy of Management Review, 27, 361-372.

Judge, T. A., Thoresen, C. J., Bono, J. E. \& Patton, G. K. (2001). The job satisfaction-job performance relationship: A qualitative and quantitative review. Psychological Bulletin, 127, 376-407.

Larson, J. H., Wilson, S. M. \& Beley, R. (1994). The impact of job insecurity on marital and family relationships. Family Relations, 43, 138.

Lazarus, R. S. \& Folkman, S. (1984). Stress appraisal and coping. New York: Springer.

Leong, S. M., Randall, D. M. \& Cote, J. A. (1994). Exploring the organizational commitment -performance linkage in marketing: a study of life insurance salespeople. Journal of Business Research, 29, 57-63.

Lim, V. K. G. (1996). Job insecurity and its outcomes: Moderating effects of work-based and nonwork-based social support. Human Relations, 49, 171-194.
Lim, V. K. G. (1997). Moderating effects of work-based support on the relationship between job insecurity and its consequences. Work \& Stress, 11, 251-266.

Mak, A. S. \& Mueller, J. (2000). Job insecurity, coping resources and personality dispositions in occupational strain. Work \& Stress, 14, 312-328.

Makikangas, A. \& Kinnunen, U. (2003). Psychosocial work stressors and well-being: Self-esteem and optimism as moderators in a one-year longitudinal sample. Personality and Individual Differences, 35, 537-557.

Mathieu, J. E. (1991). A cross-level non-recursive model of the antecedents of organizational commitment and satisfaction. Journal of Applied Psychology, 76, 1-12.

Meyer, J. P., Paunonen, S. V., Gellatly, I. R., Coffin, R. D. \& Jackson, D. N. (1989). Organizational commitment and job performance: it's the nature of the commitment that counts. Journal of Applied Psychology, 74, 152-156.

Ostroff, C. (1992). The relationship between satisfaction, attitudes, and performance: An organizational level analysis. Journal of Applied Psychology, 6, 963-974.

Parker, S. K., Chimel, N. \& Wall, T. D. (1997). Work characteristics and employee well-being within a context of strategic downsizing. Journal of Occupational Health Psychology, 4, 289-303.

Parkes, K. R. (1994). Personality and coping as moderators of work stress processes: models, methods and measures. Work \& Stress, 8, 110-129.

Platt, S., Plavis, S. \& Akram G. (1999). Changing labour market conditions and health: a systematic literature review (1993-98). Dublin: European Foundation for the Improvement of Living and Work Conditions.

Probst, T. M. \& Brubaker, T. L. (2001). The effects of job insecurity on employee safety outcomes: Cross-sectional and longitudinal explorations. Journal of Occupational Health Psychology, 6, 139-159.

Probst, T. M. (2002a). The impact of job insecurity on employee work attitudes, job adaptation, and organizational withdrawal behaviors. In J.M. Brett \& F. Drasgow (Eds.), The psychology of work: Theoretically based empirical research (pp. 141-168). New Jersey: Lawrence Erlbaum Associates.

Probst, T. M. (2002b). Layoffs and tradeoffs: Production, quality and safety demands under the threat of job loss. Journal of Occupational Health Psychology, 7, 211-220.

Probst, T. M. (2003). Exploring employee outcomes of organizational restructuring: A solomon four-group study. Group and Organizational Management, 28, 416-439.

Probst, T. M. (2004). Safety and insecurity: Exploring the moderating effect of organizational safety climate. Journal of Occupational Health Psychology, 9, 3-10.

Rhoades, L. \& Eisenberger, R. (2002). Perceived organizational support: A review of the literature. Journal of Applied Psychology, 87, 698-714.

Riketta, M. (2002). Attitudinal organizational commitment and job performance: A meta-analysis. Journal of Organizational Behavior, 23, 257-266.

Rosenblatt, Z. \& Ruvio, A. (1996). A test of a multidimensional model of job insecurity: the case of Israeli teachers. Journal of Organizational Behavior, 17, 587-605.

Roskies, E., Louis-Guerin, C. (1990). Job insecurity in managers: Antecedents and consequences. Journal of Organizational Behavior, 11, 345-359.

Roskies, E., Louis-Guerin \& Fournier, C. (1993). Coping with job insecurity: how does personality make a difference? Journal of Organizational Behavior, 14, 617-630.

Scullen, S. E., Mount, M. K. \& Goff, M. (2000). Understanding the latent structure of job performance ratings. Journal of Applied Psychology, 85, 956-970.

Spector, P. E. (1997). Job satisfaction: Applications, assessment, causes and consequences. Thousand Oaks, CA: Sage.

Strazdins, L., D’Souza, R M., Lim, L. L., Broom, D. H. \& Rodgers, B. (2004). Job strain, job insecurity, and health: Rethinking the relationship. Journal of Occupational Health Psychology, 9, 296-305. 
Stroebe, W., \& Stroebe, M.S. (1995). Social psychology and health. Belmont, CA: Brooks/Cole Publishing.

Sverke, M. \& Hellgren, J. (2002). The nature of job insecurity: Understanding employment uncertainty on the brink of a new millennium. Applied Psychology: An International Review, 51, 23-42.

Sverke, M., Hellgren J. \& Näswall, K. (2002). No security: a meta-analysis and review of job insecurity and its consequences. Journal of Occupational Health Psychology, 7, 242-264.

Sverke, M., Hellgren, J., Näswall, K., Chirumbolo, A., De Witte, H. \& Goslinga, S. (2004). Job insecurity and union membership: European unions in the wake of flexible production. Brussels: P.I.E.-Peter Lang.

Tetrick, L. E. \& LaRocco, J. M. (1987). Understanding, prediction, and control as moderators of the relationships between perceived stress, satisfaction, and psychological well-being. Journal of Applied Psychology, 72, 538-543.

Westman, M., Etzion, D. \& Danon, E. (2001). Job insecurity and crossover of burnout in married couples. Journal of Organizational Behavior, 22, 467-481.

Wilson, S. M., Larson, J. H. \& Stone, K. L. (1993). Stress among job insecure workers and their spouses. Family Relations, 42, 74-80. 